\title{
PENGARUH CITRA MEREK TERHADAP MINAT BELI : STUDI PADA PRODUK KECANTIKAN
}

\author{
Ninda Fauziah ${ }^{1}$, Dadan Abdul Aziz Mubarok ${ }^{2}$ \\ ${ }^{1,2}$ Program Studi Manajemen, STIE Indonesia Membangun, Bandung, Indonesia \\ nindafauziah64@gmail.com¹, dadan.aziz.mubarok@gmail.com²
}

\begin{abstract}
This study aims to analyze the influence of brand image on buying interest Safi brand Skincare products in the city of Bandung. The research method uses a quantitative research method approach. The research sample of 99 respondents. Data obtained by crossing the questionnaire. Data analysis using linear regression. Dimensions to measure the effect of brand image on consumer buying interest are consumer perceptions, product brand slogans and brand positioning. The results of the study explain that brand image significantly influences buying interest. The theoretical implication of this research is brand image influences buying interest with a very strong (positive) relationship and is proportional. While the implications of the study are aimed at the skincare cosmetics industry, it is expected to become one of the references in business management by optimizing brand utilization, because brand is one of the most influential things and can be used as a very promising and profitable means for marketing strategies
\end{abstract}

Keywords: brand image; purchase intention; skincare; brand

\begin{abstract}
Abstrak
Penelitian ini bertujuan untuk menganalisis pengaruh citra merek terhadap minat beli produk Skincare merek Safi di Kota Bandung. Metode penelitian menggunakan pendekatan metode penelitian kuantitatif. Sampel penelitian sebanyak 99 responden. Data diperoleh dengan menyeberkan kuesioner. Analisis data menggunakan regresi linier. Dimensi untuk mengukur pengaruh citra merek terhadap minat beli konsumen adalah persepsi konsumen, slogan merek produk dan positioning merek. Hasil penelitian menjelaskan bahwa citra merek secara signifikan mempengaruhi minat beli. Implikasi teoritis dari penelitian ini adalah citra merek mempengaruhi minat beli dengan hubungan yang sangat kuat (positif) dan berbanding searah. Sedangkan implikasi studi ditujukan untuk industri kosmetik perawatan kulit (skincare), diharapkan dapat menjadi salah satu acuan dalam pengelolaan bisnis dengan mengoptimalkan pemanfaatan merek, karena merek merupakan salah satu hal yang paling berpengaruh dan dapat dijadikan sebagai sarana yang sangat menjanjikan dan menguntungkan untuk strategi pemasaran.
\end{abstract}

Kata Kunci: citra merek; minat beli; skincare; merek

Corresponding author: Email : nindafauziah64@ gmail.com

History of article : Received: Desember 2018, Revised : Februari 2019, Published: April 2019 


\section{PENDAHULUAN}

Berlimpahnya produk kecantikan atau skincare yang ada di Indonesia disebabkan oleh antusias dari konsumen yang tinggi. Industri kosmetik nasional tumbuh sebesar $7,36 \%$ pada kuartal I. Angka ini meningkat jika dibandingkan tahun 2017 yang tumbuh sebesar 6,35\% (okezone.com/2018). Hal ini tidak terlepas dari prospek bisnisnya yang masih cukup kemilau pada masa mendatang. Berdasarkan kondisi tersebut, Indonesia merupakan potential market bagi para pengusaha industri kecantikan baik dari luar maupun dalam negeri. Skincare sebagai salah satu kategori produk kosmetik, saat ini banyak tersebar di Indonesia. Berdasarkan hasil penelusuran peneliti, cukup banyak produk skincare yang ditawarkan, dan menjadi referensi pilihan untuk konsumen. Berikut merupakan daftar produk skincare yang tersebar di indonesia yang disajikan dalam Tabel 1.

Tabel 1 (Daftar Skincare Yang Tersebar di Indonesia)

\begin{tabular}{|c|l|c|}
\hline NO & $\begin{array}{l}\text { Produk Skincare } \\
\text { di Indonesia }\end{array}$ & $\begin{array}{c}\text { Jumlah produk } \\
\text { yang dimiliki }\end{array}$ \\
\hline 1 & Leneige Skincare & 34 produk \\
\hline 2 & Safi Skincare & 33 Produk \\
\hline 3 & Emina Skincare & 20 Produk \\
\hline 4 & $\begin{array}{l}\text { Clean and clear } \\
\text { Skincare }\end{array}$ & 12 Produk \\
\hline 5 & wardah Skincare & 12 Produk \\
\hline 6 & Cetaphil Skincare & 10 Produk \\
\hline
\end{tabular}

Sumber: $\quad$ leneige.com, safiindonesia.com, eminakosmetik, clean and clear.id, wardahbeuaty.com,cetaphil.com

Menurut Tabel 1.1 terungkap bahwa ada dari 6 (enam) produk skincare yang tersebar di Indonesia dan setiap produk skincare memiliki item produk yang ditawarkan rata - rata lebih dari 10 produk. Hal ini menunjukkan bahwa kondisi persaingan produk skincare cukup ketat dengan tetap memberikan peluang bisnis yang masih memiliki potensi tumbuh dan berkembang seiring dengan daya tarik industri produk ini yang cukup besar. Salah satu produk kecantikan yang tersebar di Indonesia dan kini sedang ramai diperbincangkan adalah produk merek Safi yaitu salah satu produk kosmetik dari Malaysia yang kini memasuki pasar Indonesia

Safi Skincare mengeluarkan 33 produk yang dibagi menjadi 3 segmen pasar yaitu safi white natural untuk remaja, safi white expert untuk dewasa kisaran usia 21 sampai 35 tahun dan safi age davy untuk wanita dewasa diatas usia 35 tahun.berikut merupakan data penjualan safi skincare yang selengkapnya disajikan dalam Gambar 1.

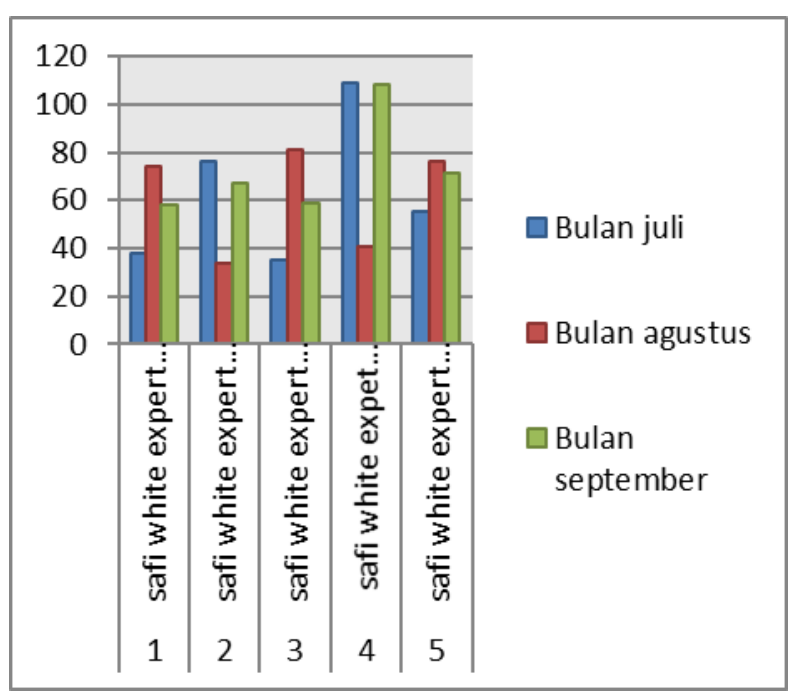

Sumber: Safiofficialstore

Gambar 1. Penjualan Pasar Produk Safi skincare

Berdasarkan Gambar 1. penjualan safi skincare pada bulan juli sampai dengan bulan September mengalami fluktuasi. Seperti safi white expert day cream $25 \mathrm{gr}$ pada bulan Juli Agustus mengalami kenaikan yang cukup tinggi sebesar 94\%. Pada bulan September mengalami penurunan penjualan sebesar $22 \%$. Untuk safi white expert day cream $45 \mathrm{gr}$ mengalami penurunan pada bulan Juli Agustus sebesar 55\% dan mengalami kenaikan cukup dibulan berikutnya yakni sebesar 97\%, kemudian untuk produk night cream $25 \mathrm{gr}$ mengalami kenaikan sangat pesat yakni sebesar $131 \%$ dari bulan Juli - Agustus namun ternyata menurun dari bulan Agustus September sebesar $27 \%$ sedangkan untuk produk night cream $45 \mathrm{gr}$ telah mengalami penurunan sebesar $62 \%$ dari bulan Juli Agustus namun ternyata mengalami kenaikan sangat pesat sebesar $163 \%$. Produk 2in1 
cleanser mengalami kenaikan pada bulan Juli Agustus sebesar $38 \%$ dan mengalami penurunan dibulan September sebesar $7 \%$. Deskripsi penjualan produk skincare merek Safi, menjelaskan tentang adanya minat beli terhadap produk tersebut di pasar Indonesia.

Minat beli merupakan kecenderungan konsumen untuk membeli suatu merek atau mengambil tindakan yang berhubungan dengan pembelian yang diukur dengan tingkat kemungkinan konsumen melakukan pembelian menurut Ali Hasan (2013: 173). Minat beli merupakan salah satu hal yang penting dalam sebuah perusahaan meskipun minat beli tidak berpengaruh langsung dalam penjualan namun minat beli merupakan sebuah proses dalam meningkatkan penjualan produk perusahaan, Banyak faktor yang mempengaruhi dan meningkatkan minat beli salah satunya adalah citra merek atau brand image pada suatu produk, hal ini sesuai dengan penelitian terdahulu yang dilakukan oleh Adhi, Daniel Sidharta, Helena (2017), Hatane Semuel Adi Suryanata Lianto (2014), dan E. Desi Aristasri Rahayu Tri Astuti (2011).

Merek akan dihubungkan dengan citra khusus yang mampu memberikan asosiasi tertentu dalam benak konsumen. Suatu merek apabila posisinya sudah kuat, akan memudahkan perusahaan dalam memenangkan persaingan yang ada di pasar. Brand image produk sangatlah penting agar dapat mempertahankan dan bahkan dapat meningkatkan minat beli konsumen. Tjiptono (2011:112) mendefinisikan citra merek yakni deskripsi tentang asosiasi dan keyakinan konsumen terhadap merek tertentu.

Memiliki citra merek yang baik tentu harus dimiliki oleh semua produk terlebih lagi pada produk skincare. Produk skincare yang beredar di pasar Indonesia banyak yang menggunakan bahan alami dan aman untuk kulit serta berlabel halal. Kini produsen produk kecantikan memang mulai serius memperhatikan kehalalan produknya, dengan memiliki label halal pada produk memungkinkan bertambahnya nilai atau citra merek pada suatu produk.

Safi merupakan salah satu brand kosmetik yang memiliki research penelitian sendiri yakni dikembangkan di Safi Research Institute, Institut Halal pertama di dunia.
Ilmuwan di Safi Research Institute berinteraksi dengan wanita muslim Indonesia untuk mengerti kebutuhan mereka akan skincare yang Halal, Alami dan Teruji . Kebutuhan akan skincare halal semakin bertambah dan membuat citra merek terhadap produk yang halal bertambah baik, citra safi sebagai produk yang halal turut aktif dalam membangun citra merek karena melalui sertifikasi halal pada produk dapat meningkatkan minat beli masyarakat terhadap produk tersebut.

Berdasarkan kondisi tersebut, maka penelitian ini bertujuan untuk mengetahui pengaruh citra merek terhadap minat beli konsumen.

\section{KAJIAN PUSTAKA \\ Minat Beli}

Menurut Setiadi (2013: 342) minat beli adalah sebagai berikut: "Proses pengintegrasian yang mengkombinasikan pengetahuan untuk untuk mengevaluasi dua atau lebih perilaku alternatif dan memilih salah satu diantaranya. Hasil dari proses pengintegrasian adalah suatu pilihan yang disajikan secara kognitif sebagai keinginan berperilaku".

Schiffman dan Kanuk (2012: 201) menyatakan bahwa minat merupakan salah satu aspek psikologis yang memiliki pengaruh cukup besar terhadap sikap perilaku. Penilaian konsumen terhadap produk tergantung pada pengetahuannya akan informasi tentang fungsi sebenarnya dari produk tersebut, dengan demikian konsumen yang berminat untuk melakukan pembelian suatu produk dipengaruhi oleh informasi yang diterima.

Berdasarkan definisi dari dua ahli diatas dapat diketahui bahwa minat beli merupakan kecenderungan konsumen dalam memilih alternatif produk dengan mencari informasi sebelum melakukan tindakan pembelian.

Menurut Durianto (2010: 59) pembelian nyata merupakan sasaran akhir konsumen yang merupakan pernyataan mental konsumen yang merefleksikan perencanaan untuk membeli sejumlah produk dan merek tertentu. Lebih lanjutnya menurut Durianto (2010: 58) mengungkapkan bahwa minat beli timbul karena adanya keyakinan konsumen terhadap suatu produk, dimana semakin rendah 
keyakinan konsumen terhadap suatu produk maka semakin rendah minat beli konsumen terhadap produk tersebut.

Minat beli terhadap suatu produk juga dapat terjadi dengan adanya pengaruh dari orang lain yang dipercaya oleh calon konsumen, konsumen juga terkadang merasa sangat tertarik terhadap berbagi informasi seputar produk yang diperoleh melalui iklan, pengalaman orang yang telah menggunakannya, dan kebutuhan yang mendesak terhadap suatu produk. Menurut Kotler (2012: 207), dalam tahap evaluasi proses keputusan pembelian, konsumen membentuk kesukaaan/minat atas merekmerek dalam sekumpulan pilihan-pilihan, konsumen juga mungkin membentuk minat untuk produk yang paling disukai. Adapun Indikator-indikator minat beli menurut Schiffman dan Kanuk (2012:470), indikator minat beli seorang konsumen adalah sebagai berikut:

1. Ketertarikan mencari informasi yang lebih tentang produk.

2. Mempertimbangkan untuk membeli.

3. Keinginan untuk mengetahui produk.

4. ketertarikan untuk mencoba produk.

\section{Citra Merek}

Citra merek dibangun berdasarkan kesan, pemikiran ataupun pengalaman yang dialami seseorang terhadap merek yang pada akhirnya akan membentuk sikap terhadap merek yang bersangkutan (Setiadi dalam Pratiwi, Suwendra, Yulianthini 2014). citra merek adalah seperangkat asosiasi-asosiasi unik yang ingin diciptakan atau dipelihara oleh pemasar. Asosiasi itu menyatakan apa sesungguhnya merek dan apa yang dijanjikan kepada konsumen (Simamora dalam Sangadji dan Sopiah 2013:327).

"Citra Merek adalah persepsi tentang merek yang merupakan refleksi memori konsumen akan asosiasinya pada merek tersebut" (Ferrina Dewi dalam Musay,2013).

Citra Merek terdiri dari tiga konponen yaitu Citra Perusahaan, Citra Konsumen, dan Citra Produk. Citra Perusahaan adalah asosiasi yang berkaitan dengan organisasi dengan atribut dari suatu perusahaan, semakin baik citra suatu perusahaanmaka produk-produk dari perusahaan tersebut akan lebih mudah diterima oleh konsumen (Biels dalam Xian, et al.2011:2)

Citra merek adalah persepsi yang dimiliki oleh konsumen saat pertama kali mendengar slogan yang diingat dan tertanam di benak konsumen Sebuah merek adalah seperangkat asosiasi yang terangkai dalam berbagai bentuk yang bermanfaat (Kotler and Keller 2009:403) Produsen suatu produk haruslah menjaga agar brand image dari produknya tetap terjaga dengan baik. Hal ini dikarenakan brand image yang baik akan mempermudah masyarakat dalam mengenali suatu produk dan memungkinkan mereka untuk melakukan minat beli terhadap produk tersebut sehingga pada akhirnya perusahaan akan memperoleh laba yang lebih besar.

Berdasarkan hal tersebut, maka faktor - faktor ysng membentuk citra merek, diantaranya adalah sebagai berikut :

1 Persepsi konsumen

2 Slogan merek produk

3 Positioning merek

\section{METODE PENELITIAN}

Metode penelitian adalah cara ilmiah untuk mendapatkan data dengan tujuan dan kegunaan tertentu (Sugiyono, 2017:2). Penelitian ini menggunakan metode deskriptif dan metode verifikatif dengan pendekatan kuantitatif. Maka, dalam melakukan penelitian ini, akan digunakan pendekatan kuantitatif dengan metode survey.

Dalam sebuah penelitian terdapat beberapa variabel yang harus ditetapkan dengan jelas sebelum mulai pengumpulan data. Penelitian ini mencakup dua variable, yaitu Minat Beli (Y) pada Safi Skincare sebagai variabel terikat (dependen variabel), dan Citra Merek (X) pada Safi Skincare sebagai variabel bebas (independen variabel). Untuk melakukan pengolahan data, diperlukan unsur lain yang berhubungan dengan variabel seperti konsep variabel, dimensi, indikator, ukuran, dan skala di mana variabel penelitian akan diukur dengan skala interval. Minat beli diukur dengan dimensi ketertarikan mencari informasi yang lebih tentang produk, mempertimbangkan untuk membeli. keinginan untuk mengetahui produk, ketertarikan untuk mencoba, Variabel citra merek diukur dengan 
dimensi persepsi konsumen, slogan merek produk, dan positioning produk.

Teknik sampling adalah teknik menentukan sampel yang akan digunakan dalam penelitian (Sugiyono 2017:81). Penelitian ini akan menggunakan teknik nonprobability sampling dengan kriteria sampel dalam penelitian ini adalah followers dari Instagram safioffcical. Ukuran sampel digunakan rumus Slovin. Ukuran populasi 203.000 dengan $e=0,10$, sehingga diperoleh ukuran sampel adalah 99 responden.

Data yang telah valid berikutnya diuji dalam serangkaian uji asumsi klasik, antara lain: uji normalitas, heteroskedastisitas, mutlikolineraritas, dan Linearitas. Uji Asumsi dasar digunakan untuk mengetahui pola dan varian serta kelineratisan dari suatu populasi atau data (Syofian Siregar 2013:153) antar variabel dependen atau variabel independen. Tahapan analisis dimulai dengan uji regresi linier sederhana untuk memperkirakan atau meramalkan nilai variabel dependen terhadap variabel independen yang menaik atau menurun. Analisis ini didasarkan pada hubungan satu variabel dependen dengan satu atau lebih variabel independen. Adapun persamaan regresi linier sederhana sebagai berikut:

$$
\mathbf{Y}^{\prime}=\mathbf{b}_{\mathbf{0}}+\mathbf{b}_{1} \mathbf{X}
$$

$\mathrm{Y}^{\prime}=$ Minat Beli (Variabel dependen)

$\mathrm{b}_{0}=$ Konstanta

$\mathrm{b}_{1}=$ Koefisien regresi

$X=$ Citra Merek (Variabel Independen)

Analisis regresi dilanjutkan dengan analisis korelasi bivariate untuk melihat hubungan antara dua variabel, yaitu erat atau rendah dan arah hubungan searah atau berbanding terbalik. Keeratan hubungan maka dapat dilihat pada besarnya koefisien korelasi dengan pedoman yaitu jika koefisien semakin mendekati 1 atau -1 maka hubungan erat atau kuat dan searah, sedangkan jika koefisien semakin mendekati 0 maka hubungan lemah dan berbanding terbalik.

Arah hubungan antara dua variable dapat terlihat dari nilai koefisien yang menghasilkan hasil positif atau negatif, sementara hubungan dua variable tersebut dinyatakan searah atau berbanding terbalik dapat diketahui melalui pengujian signifikansi.

Pengukuran nilai $\mathrm{R}^{2}$ terletak antara 0 sampai dengan $1\left(0 \leq \mathrm{R}^{2} \leq 1\right)$. Tujuan menghitung koefisien determinasi adalah untuk mengetahui pengaruh variabel bebas terhadap variabel terikat. Semakin besar nilai $\mathrm{R}^{2}$ (mendekati 1), semakin besar nilai tersebut maka model regresi semakin baik. Nilai $R^{2}$ mempunyai karakteristik diantaranya: 1) selalu positif, 2) Nilai $\mathrm{R}^{2}$ maksimal sebesar 1. Jika nilai $\mathrm{R}^{2}$ sebesar 1 maka mempunyai arti kesesuaian yang sempurna. Maksudnya seluruh variasi dalam variabel $\mathrm{Y}$ dapat diterangkan oleh model regresi. Sebaliknya jika $\mathrm{R}^{2}$ sama dengan 0 , maka tidak ada hubungan linier antara $\mathrm{X}$ dan $\mathrm{Y}$. Koefisien determinasi digunakan untuk mengukur atau mengetahui seberapa besar perubahan variabel terikat dijelaskan atau ditentukan oleh variabel bebasnya (Sugiyono, 2017:22). Besarnya pengaruh Citra Merek terhadap Minat Beli dapat ditentukan dengan menghitung koefisien determinasi dengan rumus $K d=R^{2} \times 100 \%$.

Lalu, dilakukan uji t (parsial) yang digunakan untuk menunjukkan seberapa besar pengaruh satu variabel bebas atau independen secara individual dalam menerangkan variabel terikat atau dependen. Hipotesis nol $\left(\mathrm{H}_{\mathrm{o}}\right)$ yang hendak diuji menghitung pengaruh $\rho X Y$ sama dengan nol, yang artinya terdapat pengaruh antara variable independen terhadap dependen (signifikansi). Sebaliknya, jika hipotesis alternatifnya $\left(\mathrm{H}_{\mathrm{a}}\right)$ menunjukkan bahwa $\rho X Y$ tidak sama dengan nol, artinya variabel tersebut tidak terdapat pengaruh antara variable independen terhadap dependen (tidak signifikansi).

\section{HASIL DAN PEMBAHASAN}

Hasil pengujian validitas dan reliabilitas menunjukkan hasil valid dan reliabel. Hasil Tabel 3 di atas menunjukkan bahwa 9 pertanyaan dari 12 pertanyaan menunjukkan hasil valid dan kedua hubungan variable tersebut menunjukkan hasil yang reliable dimana artinya indikator pertanyaan tersebut telah memenuhi persyaratan uji validitas dan realibilitas.

Karakteristik responden dikelompokkan menurut usia, pekerjaan, pendapatan, apakah 
pernah mencoba, dan pengalaman mencoba produk. Sebaran responden didasarkan pada usia adalah $28 \%$ responden berusia $18-20$ tahun, $62 \%$ responden usia 20-25 tahun, 4\% responden usia 25-30 tahun dan 2\% responden berusia $30-35 \%$

Untuk pekerjaan responden di bagi kedalam tiga jenjang, yaitu $66 \%$ pelajar/mahasiswa, 5\% ibu rumah tangga, dan $29 \%$ karyawan. Selain itu jenis pekerjaan responden juga terbagi menjadi tiga kategori yang paling banyak diisi, antara lain $85 \%$ sebagai mahasiswa/siswa, $10 \%$ sebagai pegawai Swasta, dan 5\% pekerjaan lainnya.

Sedangkan untuk pendapatan responden, yaitu $43 \%$ kurang dari Rp. 500.000, 22\% berpendapatan Rp. 500.000 - Rp. 1.000.000, $13 \%$ responden memiliki pendapatan $\mathrm{Rp}$. 1.000 .000 - Rp. 2.000.000 dan $22 \%$ responden > Rp. 2.000.000.

Responden yang pernah mencoba produk 29\% , sedangkan $71 \%$ responden belum pernah mencoba. Produk safi skincare yang ingin atau pernah responden coba terbagi menjadi 4 , yaitu $49 \%$ mengiginkan facial wash, 9\% ingin produk cream siang, 9\% menginginkan produk cream malam dan yang terakhir $33 \%$ responden menginginkan Purifying cleanser 2in1.

Berdasarkan hasil correlations menyatakan bahwa antara Citra Merek (X) dengan Minat Beli (Y) memiliki hasil koefisien korelasi sebesar 0,739 artinya hubungan diantara dua variabel sangat kuat dan hubungan searah (Apabila Citra Merek semakin baik/meningkat maka Minat Beli akan semakin baik/meningkat). Analisis selanjutnya adalah dengan menformulasikan persamaa regresi Diperoleh hasil seperti Tabel 2.

Nilai-nilai koefisien dapat dilihat pada Tabel 2 coefficients $^{\mathrm{a}}$ dan dimasukkan pada persamaan regresi sebagai berikut: $\mathrm{Y}^{\prime}=4,808$ + 0,972X Konstanta sebesar 4,808 yang menunjukkan bahwa jika Citra Merek tidak mengalami perubahan $(X=0)$, maka Minat Beli (Y) mencapai skor sebesar 4,808. Berikutnya koefisien regresi variabel $\mathrm{X}=$ 0,972 menunjukkan bahwa setiap kenaikan Citra Merek sebesar 100 satuan skor, maka akan diikuti oleh kenaikan Minat Beli sebesar 97,2 skor (dengan asumsi faktor lain tetap).
Kemudian dari tabel tersebut juga diketahui bahwa nilai signifikansi penelitian untuk variabel Citra Merek yaitu t hitung sebesar 7,109 lebih besar daripada $t$ tabel sebesar 2,017 dan nilai signifikansi 0,000 yang lebih kecil daripada derajat kepercayaan $\alpha=5$ persen $(0,05)$. Hal ini menunjukkan bahwa hipotesis nol $\left(\mathrm{H}_{0}\right)$ yang diajukan dalam penelitian ini, yaitu Citra Merek (variabel independent) berpengaruh signifikan terhadap Minat Beli (variabel dependent) pada Safi Skincare dan hipotesis satu $\left(\mathrm{H}_{1}\right)$ tersebut tidak terbukti atau ditolak secara empiris.

Tabel 2. Hasil Regresi Linier

\begin{tabular}{|c|c|c|c|c|c|c|}
\hline & & & efficient & & & \\
\hline & del & $\begin{array}{r}\text { Unstan } \\
\text { Coeff }\end{array}$ & $\begin{array}{l}\text { Irdized } \\
\text { ients }\end{array}$ & $\begin{array}{l}\text { Standa } \\
\text { rdized }\end{array}$ & $\mathrm{t}$ & Sig. \\
\hline & & B & $\begin{array}{l}\text { Std. } \\
\text { Error }\end{array}$ & Beta & & \\
\hline 1 & (Constant) & 4.808 & 2.204 & & 2.181 & .035 \\
\hline & $\begin{array}{l}\text { Total_Citra } \\
\text { Merek }\end{array}$ & .972 & .137 & .739 & 7.109 & .000 \\
\hline & $\begin{array}{l}\text { ependent V } \\
\text { l_Minat Be }\end{array}$ & ble: & & & & \\
\hline
\end{tabular}

Nilai-nilai koefisien dapat dilihat pada Tabel 2 coefficients $^{\mathrm{a}}$ dan dimasukkan pada persamaan regresi sebagai berikut: $Y^{\prime}=4,808$ + 0,972X Konstanta sebesar 4,808 yang menunjukkan bahwa jika Citra Merek tidak mengalami perubahan $(X=0)$, maka Minat Beli (Y) mencapai skor sebesar 4,808. Berikutnya koefisien regresi variabel $\mathrm{X}=$ 0,972 menunjukkan bahwa setiap kenaikan Citra Merek sebesar 100 satuan skor, maka akan diikuti oleh kenaikan Minat Beli sebesar 97,2 skor (dengan asumsi faktor lain tetap). Kemudian dari tabel tersebut juga diketahui bahwa nilai signifikansi penelitian untuk variabel Citra Merek yaitu t hitung sebesar 7,109 lebih besar daripada t tabel sebesar 2,017 dan nilai signifikansi 0,000 yang lebih kecil daripada derajat kepercayaan $\alpha=5$ persen $(0,05)$. Hal ini menunjukkan bahwa hipotesis nol $\left(\mathrm{H}_{0}\right)$ yang diajukan dalam penelitian ini, yaitu Citra Merek (variabel independent) berpengaruh signifikan terhadap Minat Beli (variabel dependent) pada Safi 
Skincare dan hipotesis satu $\left(\mathrm{H}_{1}\right)$ tersebut tidak terbukti atau ditolak secara empiris.

Tabel 3 (Hasil Uji Analisis Korelasi Sederhana)

\begin{tabular}{|l|r|r|r|r|}
\hline \multicolumn{5}{|c|}{ Model Summary $^{\mathrm{b}}$} \\
\hline $\begin{array}{l}\text { Mo } \\
\text { del }\end{array}$ & $\mathrm{R}$ & $\begin{array}{c}\mathrm{R} \\
\text { Square }\end{array}$ & $\begin{array}{c}\text { Adjusted R } \\
\text { Square }\end{array}$ & $\begin{array}{c}\text { Std. } \\
\text { Error of } \\
\text { the } \\
\text { Estimate }\end{array}$ \\
\hline 1 & $.739^{\mathrm{a}}$ & .546 & .535 & 2.478 \\
\hline $\begin{array}{l}\text { a. Predictors: (Constant), Total_Citra } \\
\text { Merek }\end{array}$ & \\
\hline \multicolumn{3}{|l|}{ b. Dependent Variable: total_Minat Beli } & \\
\hline
\end{tabular}

Analisis korelasi digunakan untuk mencari besarnya korelasi antara Minat Beli(X) terhadap Minat Beli(Y). Berdasarkan Tabel 5 di atas, diperoleh nilai koefisien ( $R$ square) sebesar 0,546 artinya hubungan diantara dua variabel sangat kuat dan hubungan searah artinya apabila Citra Merek semakin meningkat maka Minat Beli akan semakin baik/meningkat. Berdasarkan analisis korelasi koefisien determinasi diperoleh hasil dari rumus $\mathrm{Kd}=0,546^{2} \times 100 \%=0,739 \times$ $100 \%=73,9 \%$, dimana berarti variabel Citra Merek memiliki pengaruh terhadap Minat Beli konsumen sebesar $73,9 \%$. Sedangkan sisanya yaitu sebesar $26,1 \%$ dipengaruhi oleh faktor lain diluar model penelitian ini.

Tabel 4. Uji Analisis Koefisien Korelasi

\begin{tabular}{|c|c|c|c|}
\hline \multicolumn{4}{|l|}{ Correlations } \\
\hline & & Total_x1 & total_Y \\
\hline \multirow[t]{3}{*}{$\begin{array}{l}\text { Total_Citra } \\
\text { Merek }\end{array}$} & $\begin{array}{l}\text { Pearson } \\
\text { Correlation }\end{array}$ & 1 & $.739^{* *}$ \\
\hline & Sig. (2-tailed) & & .000 \\
\hline & $\mathrm{N}$ & 44 & 44 \\
\hline \multirow[t]{3}{*}{$\begin{array}{l}\text { Total_Minat } \\
\text { Beli }\end{array}$} & $\begin{array}{l}\text { Pearson } \\
\text { Correlation }\end{array}$ & $.739^{* *}$ & 1 \\
\hline & Sig. (2-tailed) & .000 & \\
\hline & $\mathrm{N}$ & 44 & 44 \\
\hline \multicolumn{4}{|c|}{ **. Correlation is significant at the 0.01 level (2-tailed). } \\
\hline
\end{tabular}

Berdasarkan keseluruhan hasil data yang telah diperoleh dan diolah, peneliti menemukan hasil bahwa Citra Merek pada (Safi Skincare) memiliki pengaruh yang sangat tinggi/kuat dan positif sehingga memiliki hubungan yang searah terhadap nilai Minat Beli Produk Safi Skincare. Dimana Citra Merek mampu memberikan pengaruh sebesar 97,2\% kepada minat beli konsumen akan Produk Safi Skincare. Dapat dikatakan jika pengaruh citra merek terhadap nilai minat beli sangat tinggi.

\section{KESIMPULAN DAN SARAN}

Hasil penelitian menjelaskan bahwa citra merek berpengaruh terhadap minat beli konsumen. Hal ini berdasarkan, hasil uji analisis regresi sederhana yaitu Citra Merek (variabel independent) berpengaruh signifikan terhadap Minat Beli (variabel dependent) pada Safi Skincare dan hipotesis satu $\left(\mathrm{H}_{1}\right)$ tersebut tidak terbukti atau ditolak secara empiris.sedangkan berdasarkan hasil uji analisis korelasi sederhana terdapat hasil jika hubungan diantara dua variabel sangat kuat dan hubungan searah artinya apabila citra merek semakin meningkat maka Minat Beli akan semakin baik/meningkat, dan diuji dengan Analisis Koefisien Korelasi didapat hasil bahwa hubungan diantara dua variabel sangat kuat dan hubungan searah. Dengan hasil analisis mengenai subjek dan objek penelitian yang telah dilakukan dengan memperhatikan aspek teoritis maupun aspek praktisnya yang kemudian terolah dan terkumpul pada analisis mengenai pengaruh citra merek terhadap minat beli safi skincare.

Pada konsumen safi skincare, maka dapat disimpulkan bahwa hasil dari penelitian ini adalah positif dan signifikan. Hal ini terjadi karena safi skincare memiliki pesona sendiri dalam segi merek meski dibayang- bayangi oleh produk yang telah lama terkenal di Indonesia seperti wardah namun tidak dapat dipungkiri bahwa ternyata safi mampu mengikuti persaingan produk skincare di Indonesia meskipun belum bisa dikatakan bahwa safi sejajar dengan wardah. Besarnya pengaruh minat beli pada safi skincare di Indonesia kemungkinan dikarenakan ciri khas merek yang unik dan berhasil menarik 
konsumen memiliki minat untuk melakukan pembelian pada produk safi skincare.

\section{DAFTAR PUSTAKA}

Hasan, Ali. (2011). Manajemen Bisnis Syari'ah.Pustaka Pelajar. Yogyakarta

Tjiptono, Fandy. (2011). Manajemen \& Strategi Merek. Andi. Yogyakarta.

Schiffman, L., dan Kanuk, L. (2012). Consumer Behavior. 10th Edition. Pearson Prentice Hall.New Jersey.

Kotler, P., dan Keller, K (2012). Manajemen Pemasaran (edisi 12). Erlangga. Jakarta.

Sugiyono. (2017). Metode Penelitian Kuantitatif, Kualitatif, dan $R \& D$. Alfabeta. Bandung.

Sugiyono. (2017). Statitiska Untuk Penelitian. Alfabeta. Bandung.

Syofian, Siregar. (2013). Metode Penelitian Kuantitatif. Kencana Prenada Media Group. Jakarta.

Xian, Gou Li. 2011. Corporate Product and UserImage Dimensions and Purchase Intention. Journal of Computers, (6)9: 18751879.

Adhi, Daniel Sidharta Helena. (2017). Pengaruh Citra Merek dan Kualitas Produk Terhadap Minat Beli Konsumen Porkball. Jurnal Manajemen dan Start-Up Bisnis.

Eka Desyani Wahyuningsih Ponirin. (2016) Pengaruh Persepsi Harga dan Citra Merek terhadap Minat Beli Produk Motor Merek Yamaha Nmax di Kota Palu. Jurnal Ilmu Manajemen, 3, 229240.

Hatane Semuel \& Adi Suryanata Lianto Analisis Ewom, Brand Image, Brand Trust Dan Minat Beli Produk Smartphone Di Surabaya. Jurnal Manajemen Pemasaran, 8 (2), Oktober 2014 doi: 10.9744/pemasaran.8.2.4754 ISSN 1907-235X 
Journal IMAGE | Volume 8, Number 1, April 2019, page 37-44 
Journal IMAGE | Volume 8, Number 1, April 2019, page 37-44 
Journal IMAGE | Volume 8, Number 1, April 2019, page 37-44 